\title{
XV Symposium Internacional sobre el Prácticum y las Prácticas Externas "Presente y retos de futuro"
}

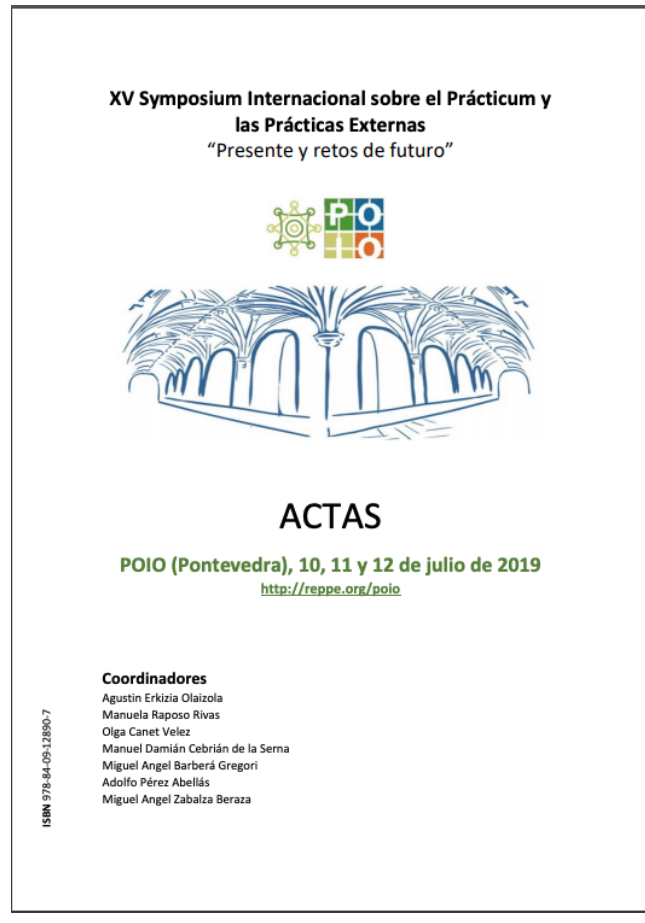

Organización:

La Asociación para el Desarrollo del Prácticum y de las Prácticas Externas: Red de Prácticum (REPPE)

https://reppe.org/

\section{Coordinadores:}

Agustin Erkizia Olaizola Manuela Raposo Rivas

Olga Canet Velez Manuel Damián Cebrián de la Serna Miguel Angel Barberá Gregori Adolfo Pérez Abellás Miguel Angel Zabalza Beraza

XV Symposium Internacional sobre el Prácticum y las Prácticas Externas "Presente y retos de futuro"

Celebrado el 10 a 12 julio 2019, Poio (Pontevedra), España 
En esta edición hemos preparado un programa académico y socio cultural que permite reflexionar sobre el tema que nos ocupa desde el presente, pero con una clara mirada hacia los retos que este espacio privilegiado del aprendizaje en el prácticum y las prácticas externas nos plantea en el futuro. El Symposium estuvo dirigido a profesionales interesados en compartir conocimientos y experiencias desde las diferentes disciplinas sobre la temática del Symposium internacional.

A continuación disponen de toda la información y documentos producidos:

\section{Programa}

https://bit.ly/2E5gMrO

Las conferencias y mesas redondas fueron grabadas en vídeo por la Universidad de Vigo y están disponibles en:

https://bit.ly/38kpaSk

Las actas puede bajarse en:

https://bit.ly/2YubU9k

Todas las comunicaciones se encuentran recogidas en esta base de datos:

https://bit.ly/2LDfdFU 